\title{
Reading communities in the School Library: the role of web 2.0 and social media
}

\author{
Glória Bastos \\ Universidade Aberta (Portugal) / CEMRI / LE@D \\ gloria@uab.pt
}

\begin{abstract}
Literature for children and young people is taking advantage of the dynamics offered by digital world. Web tools and social media are now powerful resources to promote reading and children's literature among the new generations. These tools, due to its interactivity, open the door to new readers that find a new appeal when interacting with literature through these tools. Taking into account this context, school libraries cannot stay apart from the possibilities that these resources can offer for reading promotion. So, in Portuguese school libraries several projects are being developed, based on the dynamics that web 2.0 tools offer. In this paper we present some results of a project developed under a master's degree in School Libraries, at the Portuguese Open University. The results of these studies show a diversity of strategies that are followed by school libraries, trying to involve various actors (teachers, students, parents), thus contributing to the development of reading skills, with positive effects on motivation, reading and writing interests and competences.
\end{abstract}

Keywords: Reading, Social media, Interpretative communities

\section{Introduction}

We currently witness the dissemination of the literary phenomenon on a global scale, accompanied by the abundant use of social networks that enrich the connections between books and readers. And literature for children and young people have also taken advantage of the dynamics they have been established in the digital world. Web tools and social media are now powerful resources to promote reading and children's literature among the new generations. These tools, due to its interactivity, open the door to new readers that find a new appeal when interacting with literature through these tools. The interactive context of Web 2.0, powered by this motivation of younger, digital natives, for online communication with their peers, makes the social dimension of reading assuming a renewed value. 
Taking into account this context, school libraries cannot stay apart from the possibilities that these resources can offer for reading promotion. So, in Portuguese school libraries several projects are being developed, based on the dynamics that web 2.0 tools offer, so that children can be at the same time a reader and a creator/author, also emphasising the social dimension that reading can assume. Under a master's degree in School Libraries, at the Portuguese Open University (Universidade Aberta), has been carried a research project aimed at studying this new context, through several case studies that examine the ways in which school libraries have boosted the promotion of reading, namely using web resources and social media.

\section{Background}

The internet has imposed a new paradigm in communicative relationships. We now live under the sign of "hiperconected generations" (Otero, 2014), and the reader is often the creator of knowledge that he/she shares with their peers through the social web. Gemma Lluch and Sandra Sánchez (2013) explain that the XXI century has created new scenarios for reading: for example, the possibility of direct communication between those who write books and those who read them. The web is also providing to children and young people new ways to communicate with all readers of a same book. We all recognise the enthusiasm with Harry Potter collection that has originated a myriad of websites around the books, all over the world and in many languages, revealing readers' interest and involvement. Sharing ideas and interpretative views of a book, in this community of virtual readers, has become a reality.

Cyberspace thus provides an ideal stage for the reinvention of traditional forms of interaction with the literary work (eg, critical comment, more or less impressive), but above all, to share ideas on a much larger scale. The possibility of many speaking to many, communicating their individual point of views and reading other's comments, sometimes on the other side of the world, allows this construction of sharing communities (and why not, learning communities?) raising in a cooperative way multiple readings of a particular story.

This situation creates very interesting challenges and new synergies between printed and digital environments (Unsworth, 2008). In fact, relations between the printed and digital world are now more complex, influencing the way young readers relate to literature. As Beagley (2012) states, this new context also challenges the concepts of author, reader, and critic:

The suddenly ubiquitous social media engendered by Web 2.0, typified by Youtube, Facebook, Twitter, personal blogs and so on, has not just given new tools for expression and open up vast new audiences. Its democratization of the act of creating a text, and presenting it to a wide audience, challenges to the core our long-held definitions of the author, the reader, the critic, the text and, particularly our traditions of learned discourse. (Beagley,2012, s/p) 
Children's literature is no exception to this logic of virtual mass communication where blogs, computer games, movies on youtube, gravitating around the literary work, are eagerly consumed by young people. Thus, as Unsworth (2008), we can also identify here "complementary synergists": the narrative worlds of children's books are expanded and reconfigured in several ways in the media. In Portuguese literature for children, like in other countries, we have several examples of authors that are now using the web and social media to present their work and to communicate with their readers. One of the major cases was Sofia's Diary series (by Marta Gomes and Nuno Bernardo) that begins on the web and only after a while took the form of printed book with a remarkable success. The story became also a TV series and had international impacts.

These various situations embody, clearly, the concept of "dynamic hybrid book" proposed by Dresang (2008). The principles of interactivity, connectivity and access that Dresang describe as main lines for books and reading in the digital age are here widely assumed. The relationship between print and digital, between offline / online, were made more complex influencing how young readers relate to literature.

From the point of view of reading promotion, the possibilities created by the web brought new dynamics that must be taken into account (Azevedo, Balça \& Bastos, 2015). One of the main aspects is related to the multiple opportunities that are created to interact with literature, in particular through the multimodal dimension of the text. Hypertext and hypermedia create multiple and diverse reading situations: animated illustrations, the ability to "give voice" to characters or selecting pieces of music accompanying the narrative are some of the hypotheses that several products brought for reading. Of course, with these special features the interpretive possibilities are enlarged to other dimensions that the text on paper would not allow (Unsworth, 2003). These new reading contexts can give a more active role to the reader. Several examples show that it is not already just to read a story or a book, even an ebook, but to actively interact with it in different ways.

\section{Methodology}

As we have said, under the master degree in School Librarianship at Universidade Aberta (Portugal) we have a research project about reading promotion. In this paper we will examine some results from one empirical study, developed under my supervision, that focus on the use of digital devices and social web to promote reading in school libraries, either in print or digital format. The study fall within the qualitative paradigm and assume a constructive interpretative approach (Denzi \& Lincoln, 2005).

The study design is based on two dimensions: first it was made a survey to all teacher librarians (TL) from a region in the north of Portugal (Viana do Castelo) corresponding to 51 teacher librarians and 74 school libraries. This survey had the following purposes: 
- To identify the level of knowledge and use of Web 2.0 tools in reading promotion.

- To characterize teacher librarians using Web 2.0 tools services in the promotion of recreational reading;

- To identify which tools are most used and in which reading promotion situations are they used.

With the results obtained it was possible to identify a group of teacher librarians who used different tools in different situations, anticipating the existence of more established practices. An interview was then applied to this group of 4 TL. With the interview it was intended:

- To know with greater detail the reasons for the use of web 2.0 and social web in the promotion of recreational reading.

- To get more accurate information about how these teacher librarians use these tools.

- To identify successful practices on using web 2.0 in reading promotion.

The application of the interview allowed us, on one hand, crossing some data with those provided in the questionnaire and, secondly, to understand more clearly how the situations described were developed by identifying thus well-established practices in the field.

\section{Results and Discussion}

The value attributed by teacher librarians to new technologies in the context that was examined is reflected in their work. We found that TL know much more tools and services than those who actually they use in their work. There is also a relation between the knowledge they have about Web 2.0 tools and their use when performing certain activities in the promotion of recreational reading.

Despite the fact that we can identify practices already grounded in the myriad of initiatives taken by some schools, their use is generally little sustained. The range of tools and Web 2.0 services presented to build content, share resources, retrieve and organize information, and to establish interaction are relatively poor. If, on one hand, the majority of teacher librarians (60\%) are familiar with about half of the tools / Web 2.0 services presented in the study, which is not negligible, $80 \%$ of them only use 2 to 5 of these tools when referring to their use in reading promotion contexts. 
Table 1. Web 2.0 tools and services used in reading promotion

\begin{tabular}{c|c|c}
\hline Web 2.0 services /tools & Frequency & \% \\
\hline Blog & 43 & $88 \%$ \\
\hline Wiki & 3 & $6 \%$ \\
\hline Google sites & 7 & $14 \%$ \\
\hline Twitter & 2 & $4 \%$ \\
\hline Moviemaker & 12 & $24 \%$ \\
\hline Podomatic & 1 & $2 \%$ \\
\hline Youtube or Vimeo & 23 & $47 \%$ \\
\hline Delicious or Diigo & 6 & $12 \%$ \\
\hline Slideshare, ISSUU or Scribd & 14 & $29 \%$ \\
\hline Picasa or Flickr & 8 & $47 \%$ \\
\hline Facebook & 23 & $39 \%$ \\
\hline Moodle & 21 & \\
\hline GoogleDocs & 19 & \\
\hline
\end{tabular}

The results also show that schools with more established practices using these tools in the promotion of recreational reading have a systematic work and in conjunction with classroom teachers. They do it throughout the school year, especially through reading projects. Book clubs, reading projects, writing workshops and blogs as a reading and writing platform are examples of activities / projects developed systematically by TL.

Table 2. Contexts where Web2.0 tools are used for reading promotion

\begin{tabular}{l|c|c}
\hline \multicolumn{1}{c|}{ Contexts } & Frequency & $\%$ \\
\hline Presentation of relevant websites & 10 & $19 \%$ \\
\hline Discussion forums & 13 & $24 \%$ \\
\hline Presentation of students writings & 26 & $48 \%$ \\
\hline For reading motivation & 17 & $31 \%$ \\
\hline Dramatization of texts & 12 & $22 \%$ \\
\hline Film production & 12 & $22 \%$ \\
\hline Book production & 13 & $24 \%$ \\
\hline Reading Clubs & 11 & $20 \%$ \\
\hline Ebook reading promotion & 27 & $50 \%$ \\
\hline Reading suggestions & 26 & $48 \%$ \\
\hline Activities publicising & 5 & $9 \%$ \\
\hline New acquisitions publicising & 22 & $41 \%$ \\
\hline
\end{tabular}


As we have already mentioned, with the survey's results we have identified a group of four teacher librarians that revealed a more consistent work. These TL were interviewed and several aspects about their profile and their work have emerged.

These teacher librarians demonstrate a proactive attitude, reflected in the broader knowledge they have about Web 2.0 tools and services. That knowledge allows them to go beyond the unilateral use of the tools. They involve students in reading animation activities giving them different responsibilities, thus developing multiple competences through the use of new technologies in recreational reading. The use of several tools to present books, to make movies about books or even pictures and music, as well as the production of new resources relating to readings, are activities that deserve a greater attention from these TL.

We noted that teacher librarians with best practices do not use new technologies in a wide-ranging way; they rather seek to tailor each tool to a specific purpose, to get the best results. They create contents, share resources with readers and, above all, they interact with them to create reading communities in the school, having the school library as a focal point.

We can also say that these TL show a remarkable ability to adapt to these new contexts, using new technologies to approach the twenty-first century reader. The reading projects they conceive are direct answers to the needs of their schools. They follow Larson's recommendations in "E-Reading and e-Responding: New Tools for the Next Generation of Readers" (2009a), when noting that there is "an urgent need for teachers and researchers to address the discrepancy between the types of literacy experiences students encounter at school (paper, pencil, and print texts), and those they practice in their daily lives outside the school environment (Web 2.0)" (p. 255).

Furthermore, the interviews revealed that these teacher librarians, who made a higher quality use of new technologies, reveal a reflective attitude to the question. They identify advantages and disadvantages of using some tools and services, drawing attention to the role that social web can have in the reading and learning process.

\section{Final Remarks}

A recent National Literacy Trust research from UK found that "print remained the favourite medium for reading fiction for most children" (Picton, 2014, p. 6) but at the same time noticing that "it is important to recognise that the use of electronic texts is becoming an increasingly important part of students' literacy learning, and the number and quality of ebooks available for children and young people to read for pleasure is increasing year on year" (p. 17). In fact, not only the use of ebooks is increasing but also young people is now living in a technological rich environment where online communication is always present.

In this context it is important to understand how school libraries and TL are responding to this new world. In the field of reading promotion we think that reading and 
responding can benefit from the use of new technologies. The study we present here shows that in Portuguese schools there is still some work to do but we can already find some examples of good practices.

In these school libraries students are put in contact with a wide variety of print and digital resources on many different subjects, using even the holiday period. They use blogs, Moodle, Facebook, Youtube or Slideshare, among other tools, to "talk" about books. They use different technological tools to transform and to reinvest their readings into a movie, a graphic novel, a digital book, a song, a play... Some of these tools, for their interactivity, open the door to new audiences. The interactive context of Web 2.0, powered by this motivation of the younger, digital natives, for online communication with their peers, gives to the social dimension of reading a renewed value. It is difficult to deny the importance that these literary communities can have in enhancing reading, creating synergies between printed and digital environments.

Teacher librarians use Web 2.0 tools to design projects involving students in different activities. They are aware of the potentials of these tools in developing reading and writing. They establish collaborative work with other teachers, or with parents to increase student's motivation. Reading clubs take new perspectives and writing workshops can be more fun and more engaging when students can use different technologies to express their thoughts and their feelings. When students can exchange ideas with writers, communicating online; or when they can discuss with colleagues from another school, several miles away. As Larson says, "the new literacies are here to stay, and it is the responsibility of all teachers to orchestrate learning opportunities in which students can collaborate and communicate within a technology-rich environment" (2009b, p. 648).

\section{References}

Azevedo, Fernando, Balça, Ângela \& Glória Bastos (2015). Web 2.0: literatura infantil / juvenil e comunidades interpretativas[Web 2.0: children's literature and for young adults and the interpretative communities]. CADERNO SEMINAL DIGITAL. v. 23, n. ${ }^{\circ}$ 23, 40-57. DOI: http://dx.doi.org/10.12957/cadsem.2015.14668

Beagley, D. (2012). Blurring the Boundaries: the changing i-discourse of children's literature, The Looking Glass: New Perspectives on Children's Literature, 16 (2). http://www.the-looking-glass.net/index.php/tlg/article/view/317/314

Bringue, X. \& Sábada, C. (2011). Menores y redes sociales. Madrid: Foro Generaciones Interactivas.

Denzi, N., Lincoln, Y. (2005). The Sage Handbook of Qualitative Research. Thousand Oaks: Sage Publications.

Dresang, E. T. (2008). Radical change revisited: Dynamic digital age books for youth. Contemporary Issues in Technology and Teacher Education, 8(3), 294-304. 
Larson, L. C. (2009a). E-reading and e-responding: New tools for the next generation of readers. Journal of Adolescent \& Adult Literacy, 53(3), 255-258.

doi:10.1598/JAAL.53.3.7.

Larson, L. C. (2009b). Reader response meets new literacies: Empowering readers in online learning communities. The Reading Teacher, 62(8), 638-648. doi: 10.1598/RT.62.8.2.

Lluch, G. \& Sánchez, S. (2013). Los retos de lectura. Reto Delirium, Pandemonium y Requiem. http://blog.smconectados.com/2013/07/15/los-retos-de-lectura-reto-deliriumpandemonium-y-requiem/

Martín-Barbero, J. \& Lluch, G. (ed.) (2011). Lectura, escritura y desarrollo en la sociedad de la información. Bogotá: Cerlalc-Unesco. http://cerlalc.org/publicacion/proyecto-lectura-escritura-y-desarrollo-en-la-sociedad-delainformacion/

Otero, M. (2014). El boom de los clubs de lectura en internet. http://www.elconfidencial.com/cultura/2014-05-04/el-boom-de-los-clubs-de-lectura-eninternet $123055 /$

Picton, I. (2014). The Impact of ebooks on the Reading Motivation and Reading Skills of Children and Young People: A rapid literature review, London: National Literacy Trust.

Sánchez García, S.; Lluch Crespo, G. \& del Río Toledo, T. (2013). La lectura al web 2.0. Estudi de cas: els blogs en el Reto Delirium. @tic. Revista d'Innovació Educativa. $\left(\mathrm{n}^{\mathrm{o}} \quad 10\right)$ DOi: 10.7203/attic.10.1783 http://ojs.uv.es/index.php/attic/article/view/1783/1996

Unsworth, L. (2003). Reframing research and literacy pedagogy relating to CD narratives: Addressing 'radical change' in digital age literature for children. Issues in Educational Research, 13(2), 55-70. http://www.iier.org.au

Unsworth, L. (2008) Multiliteracies, E-literature and English Teaching. Language and Education, 22:1, 62-75, DOI: 10.2167/le726.0

\section{Biographical note}

Glória Bastos - Professor at the Department of Education and Distance Learning, Universidade Aberta (Portuguese Open University), where she teaches Children's Literature and coordinates the first master for teacher-librarians. The areas of interest are children's literature and school libraries. She has a PhD at Portuguese Studies and has presented sessions and published several books and articles in particular about children's literature, reading promotion and school libraries. She belongs to the scientific board of the National Reading Plan and collaborates with several institutions on Teacher Training and in reading and children's literature programs. 